\title{
Antioxidative activities of various solvent extracts from haw (Crataegus pinnatifida Bunge)
}

\author{
Yishan Duan, Min-A Kim, Jong-Hwan Seong, Hun-Sik Chung, Han -Soo Kim* \\ Department of Food Science and Technology, Pusan National University, Miryang 627-706, Korea
}

\section{산사(Crataegus pinnatifida Bunge)의 추출 용매별 항산화 활성}

\author{
단의삼·김민아·성종환 · 정헌식·김한수* \\ 부산대학교 식품공학과
}

\begin{abstract}
The objective of this study was to investigate the antioxidative acitivities of various solvent extracts from haw (Crataegus pinnatifida Bunge) pulpy. The Freeze-dried pulpy of haw was extracted with five solvents $(\mathbf{7 0} \%$ methanol, 70\% ethanol, chloroform:methanol (CM, 2:1, v/v), n-butanol, and ethyl acetate or EA), and the DPPH, reducing power, fenic-reducing antioxidant power (FRAP), ABTS, NO, hydroxyl radical scavenging activity were then measured. The DPPH radical scavenging activity of the $70 \%$ methanol and $70 \%$ ethanol extracts were $92.89 \%$ and $91.17 \%$ in the $0.8 \mathrm{mg} / \mathrm{mL}$ concentrations, respectively, which were higher than those of the other extracts. The reducing power and FRAP decreased in the following order: $\mathbf{7 0 \%}$ methanol, $\mathbf{7 0 \%}$ ethanol, n-butanol, EA, and CM extracts. The ABTS radical scavenging activity was high in the $70 \%$ methanol and $70 \%$ ethanol extracts and low in the n-butanol extract. The NO radical scavenging activity was high in the $70 \%$ methanol and $70 \%$ ethanol extracts but low in the CM extracts. On the other hand, the hydroxyl radical scavenging activity was high in the $\mathbf{n}$-butanol and $70 \%$ methanol extracts but low in the EA extract. These results suggest that the $70 \%$ methanol and $70 \%$ ethanol extracts from haw will be useful as natural antioxidant and biohealth foods.
\end{abstract}

Key words : Crataegus pinnatifida Bunge, pulpy, antioxidant, DPPH, reducing power

\section{서 론}

서구화된 식생활과 함께 운동 부족, 흡연, 음주, 스트레스 등으로 인하여 비만, 고혈당, 고혈압과 같은 대사증후군의 유병률이 증가하고 있으며 이에 따라 올바른 영양관리 및 바람직한 식습관의 중요성이 강조되고 있다(1,2). Phytochemical 은 식물 유래 생리활성물질로 그 종류가 매우 다양하며 free radical 소거 등을 통하여 단백질, DNA, 지질 등의 생체 분자를 손상시키는 산화적 스트레스(oxidative stress)를 감 소시키기 때문에 이러한 생리활성물질을 포함하는 과일 및 채소의 섭취는 심혈관계 질환, 암과 같은 만성질환의 위험도를 줄일 수 있다는 점에서 주목받고 있다(3). 비만 아동은 총 콜레스테롤, low density lipoprotein(LDL)-

*Corresponding author. E-mail : kimhs777@pusan.ac.kr Phone : 82-55-350-5351, Fax : 82-55-350-5359 cholesterol, triglyceride(TG)가 정상 아동에 비하여 높은 수 준이었으며 정상 아동에 비해 상대적으로 채소 및 과일류의 섭취는 적어 올바른 영양 교육 및 식습관이 중요하다고 하였다(4). 채소와 과일은 total phenol을 많이 함유하고 있 어 radical 소거 활성과 같은 효과가 있으며, 동맥경화를 촉진하는 효소로 알려진 lipoprotein-associated phospholipase A2(Lp-PLA2)의 활성을 저해 한다고 보고되어 있다(5). 또 한, 혼합 채소 주스를 섭취하였을 경우 함유되어 있는 생리 활성물질로 인하여 혈청내 지질 수준이 개선되었고 superoxide dismutase(SOD), glutathione peroxidase(GPx)와 같은 항산화 지표의 활성은 증가하여 비만, 당뇨 등 심혈관 계 질환의 예방이 가능하다는 연구 결과도 있다(6).

산사(Crataegus pinnatifida Bunge)는 특유의 향과 맛을 가지고 있는 장미과(Rosaceae)의 열매로 우리나라 및 중국, 일본 전역에 자생하고 있으며 예로부터 소화기 질환, 고혈 압, 항비만 등의 질환에 이용되어 왔다 $(7,8)$. 생산사의 미네 
랄 함량은 칼륨이 제일 높다고 알려져 있는데 그 밖에 칼슘, 인, 망간, 아연, 철분, 구리 등의 영양 성분도 함유되어 있다 고 하며(9) corosolic acid, (-)-epicatechin, cyanidin-3-galactoside, isoquercitrin, hyperoside 등의 약리성분도 포함하고 있다고 한다 $(10,11)$. 또한, 산사 phenol compound의 대부분을 차지 하는 것은 quercetin이며 hyricetin, gentisic acid, caffeic acid, catechin, salicylic acid, ferulic acid, chlorogenic acid, narigin, p-coumaric acid도 포함되어 있다고 보고된 바 있다(12). 산 사의 생리활성으로는 트롬빈 저해 활성(13), 위장보호(14), 지방 세포의 분해(15), 혈청 및 간의 지질 농도 개선(16), 기억력 개선(17) 등의 작용이 있다고 보고되어 있다. 한편, 산사에 관한 주요 연구로는 콜레스테롤 합성과 저장에 관여 하는 HMG-CoA reductase 효소 활성 저해(18), 산사 methanol 엑스에서 분리된 ursolic acid 및 (-)-epicatechin, quercetin 등의 monoamine oxidase 활성 억제(19), D-galactose 로 노화를 유발시킨 흰쥐 적혈구의 SOD와 GSH-px 활성 증가 및 혈장 내 총 지방 농도의 감소 효과(20) 등에 대한 연구가 이루어지고 있으나 항산화 효과에 대한 지속적인 연구는 미비한 실정이다. 이에, 본 연구에서는 산사의 천연 항산화제로서의 활용 가능성을 모색하기 위하여 산사 과육 을 용매별로 추출한 후 항산화 활성을 조사하여 biohealth 기능성 식품 소재로 활용하기 위한 기초자료를 얻고자 실시 하였다.

\section{재료 및 방법}

\section{실험 재료}

본 실험에 사용한 산사는 2011년 10월 중하순 강원도 정선군 남면 일대에서 자생하는 야생 산사를 채취한 후 과육을 분리하여 시료로 사용하였다. 분리한 과육은 진공 동결건조(FDU-2000, EYELA, Tokyo, Japan) 시킨 후 분쇄 기(DCM-5500, Daechang, Seongnam, Korea)로 마쇄하여 $-80^{\circ} \mathrm{C}(\mathrm{SW}-U F-400$, Samwon Co., Busan, Korea)에 보관하며 사용하였다.

\section{시료 추출}

진공 동결된 건조 산사 분말 $100 \mathrm{~g}$ 을 취해 $70 \%$ methanol, $70 \%$ ethanol, chloroform :methanol(CM, 2:1, v/v), n-butanol, ethyl acetate (EA) 용매를 10배 가하여(1:10, w/v) 24시간 동안 추출하는 과정을 총 2회 실시한 후 여과(filter paper, Advantec, No.1, Tokyo, Japan)하였다. 각 여과액을 rotary evaporator (N-N series, EYELA)로 $40^{\circ} \mathrm{C}$ 에서 농축하여 용매 를 완전히 제거한 후, $-80^{\circ} \mathrm{C}(\mathrm{SW}-\mathrm{UF}-400, \mathrm{Samwon} \mathrm{Co}$.)에 냉동 보관하면서 실험에 사용하였다(21). 시료의 수율은 추출 전 시료 중량에 대한 추출 후 건조 중량 백분율로 나타내었고, 용매별 추출 수율은 $70 \%$ methanol 추출물
$60.45 \%, 70 \%$ ethanol 추출물 $59.79 \%$, chloroform:methanol $(2: 1, \mathrm{v} / \mathrm{v})$ 추출물 $31.18 \%, \mathrm{n}$-butanol 추출물 $13.24 \%$, ethyl acetate 추출물 $5.05 \%$ 를 얻어 본 실험의 시료로 사용하였다.

\section{DPPH radical scavenging activity 측정}

산사 과육의 전자공여능(electron donating ability, EDA) 은 Blois (22)의 방법에 준하여 측정하였다. 시료 $1 \mathrm{~mL}$ 와 $0.4 \mathrm{mM}$ DPPH $2 \mathrm{~mL}$ 를 혼합하고 $37^{\circ} \mathrm{C}$ 에서 30 분간 반응시킨 후, 반응액을 UV/VIS-spectrophotometer(Specord 200, Analytik-Jena, Jena, Germany)를 이용하여 $518 \mathrm{~nm}$ 에서 흡 광도를 측정하였다.

$$
\begin{aligned}
& \text { DPPH radical scavenging activity }(\%)= \\
& \qquad\left(1-\frac{A b s_{\text {sample }}}{A b s_{\text {blank }}}\right) \times 100
\end{aligned}
$$

\section{환원력 측정}

산사 용매별 추출물의 환원력은 각 시료 용액 $1 \mathrm{~mL}$ 에 $0.2 \mathrm{M}$ phosphate buffer(pH 6.6) $2.5 \mathrm{~mL}$ 와 $1 \%$ potassium ferricyanide $2.5 \mathrm{~mL}$ 를 가하여 $50^{\circ} \mathrm{C}$ 에서 20 분간 반응시킨 후 냉각시켰다. 반응액에 $10 \%$ trichloroacetic acid(TCA) 2.5 $\mathrm{mL}$ 를 가하여 $3,000 \mathrm{rpm}$ 에서 10 분 동안 원심분리시키고, 상등액 $1 \mathrm{~mL}$ 를 취하여 증류수 $3 \mathrm{~mL}$ 및 $0.1 \%$ ferric chloride $1 \mathrm{~mL}$ 를 혼합하였다. 10분 후, UV/VIS-spectrophotometer로 $700 \mathrm{~nm}$ 에서 흡광도를 측정하였다. 환원력은 시료 용액 첨 가군의 흡광도와 무첨가군의 흡광도 차이로 나타내었다 (23).

Ferric reducing antioxidant power(FRAP) 측정

산사 과육의 추출 용매별 FRAP 활성은 Jeong 등(24)의 방법에 의하여 측정하였다. 즉, $0.3 \mathrm{M}$ sodium acetate buffer $(\mathrm{pH} \quad 3.6)$ 및 $10 \mathrm{mM}$ 2,4,6-tripyridyl-S-triazine(TPTZ) solution, $20 \mathrm{mM}$ ferric chloride를 10:1:1(v/v/v)의 비율로 혼 합하여 $37^{\circ} \mathrm{C}$ 에서 10 분간 방치시켜 FRAP 시약을 조제하여 실험에 사용하였다. 시료 $0.03 \mathrm{~mL}$ 에 FRAP 시약 $1.5 \mathrm{~mL}$ 를 가하여 $37^{\circ} \mathrm{C}$ 에서 30 분간 방치시킨 후, UV/VISspectrophotometer로 $593 \mathrm{~nm}$ 에서 흡광도를 측정하였다. FRAP는 흡광도를 항산화력으로 표시하였다.

\section{ABTS radical scavenging activity 측정}

$7 \mathrm{mM} \mathrm{ABTS}$ 와 $2.45 \mathrm{mM}$ potassium persulfate를 2:1(v/v)의 비율로 섞어 암소에서 12 16시간 동안 방치시킨 후, 이를 $5 \mathrm{mM}$ phosphate buffer(pH 7.4)와 혼합하여 $734 \mathrm{~nm}$ 에서 흡광도가 $0.7 \pm 0.02$ 가 되도록 $\mathrm{ABTS}$ 용액을 제조하였다. 시 료 $200 \mu \mathrm{L}$ 에 $\mathrm{ABTS}$ 용액 2,800 $\mu \mathrm{L}$ 를 가하여 정확히 6분 후에 $734 \mathrm{~nm}$ 에서 흡광도를 측정하여 다음의 식에 의해 radical 소거 활성을 나타내었다(25). 
ABTS radical scavenging activity $(\%)=$

$$
\left(1-\frac{A b s_{\text {sample }}}{A b s_{\text {blank }}}\right) \times 100
$$

NO radical scavenging activity 측정

산사 과육의 추출 용매별 NO radical 소거 활성은 Yang 등(26)과 Shrishailappa 등(27)의 방법에 따라 시료 $0.5 \mathrm{~mL}$ 에 $10 \mathrm{mM}$ sodium nitroprusside $0.5 \mathrm{~mL}$ 를 가하여 $25^{\circ} \mathrm{C}$ 에서 150 분간 반응시켰다. 여기에 $1 \%$ sulfanilamide $1 \mathrm{~mL}$ 및 $0.1 \%$ naphtylethylenediamide $1 \mathrm{~mL}$ 를 가한 후 $540 \mathrm{~nm}$ 에서 흡광도 를 측정하였으며 다음의 식에 의하여 NO radical 소거 활성 을 계산하였다.

NO radical scavenging activity $(\%)=$

$$
\left(1-\frac{A b s_{\text {sample }}}{A b s_{\text {blank }}}\right) \times 100
$$

Hydroxyl radical scavenging activity 측정

Hydroxyl radical 소거 활성은 시료 $1.5 \mathrm{~mL}$ 에 $10 \mathrm{mM}$ $\mathrm{FeSO}_{4} \quad 0.2 \mathrm{~mL}$ 및 $10 \mathrm{mM}$ EDTA $0.2 \mathrm{~mL}, 10 \mathrm{mM}$ 2-deoxyribose $0.2 \mathrm{~mL}, 0.1 \mathrm{M}$ phosphate buffer $2 \mathrm{~mL}, 10$ $\mathrm{mM} \mathrm{H} \mathrm{O}_{2} 0.1 \mathrm{~mL}$ 를 가하여 $37^{\circ} \mathrm{C}$ 에서 1 시간 동안 반응시켰 다. 반응액에 $2.8 \% \mathrm{TCA} 1 \mathrm{~mL}$ 와 $1 \%$ thiobarbituric acid(TBA) $0.5 \mathrm{~mL}$ 를 가하고 $100^{\circ} \mathrm{C}$ 의 water bath에서 10 분간 반응시켰 다. 반응이 끝난 후, 냉각하여 $800 \mathrm{rpm}$ 에서 10 분간 원심분리 하였고 $532 \mathrm{~nm}$ 에서 흡광도를 측정하였다. 산사 과육의 hydroxyl radical 소거 활성은 다음의 식에 의하여 나타내었 다(29).

Hydroxyl radical scavenging activity $(\%)=$

$$
\left(1-\frac{A b s_{\text {sample }}}{A b s_{\text {blank }}}\right) \times 100
$$

\section{결과 및 고찰}

\section{DPPH radical scavenging activity}

산사 과육의 2, 2-diphenyl-1-picrylhydrazyl(DPPH)에 대 한 전자공여능은 Fig. 1과 같으며 대조군인 ascorbic acid를 제외한 모든 실험군에서 농도 의존적으로 증가하는 경향을 보였다. $70 \%$ methanol 추출물은 $0.2 \mathrm{mg} / \mathrm{mL}, 0.5 \mathrm{mg} / \mathrm{mL}$, $0.8 \mathrm{mg} / \mathrm{mL}$ 농도에서 각각 $28.21 \%, 64.52 \%, 92.89 \%$ 로 나타 나 추출 용매 중 가장 높은 활성을 보였고 $70 \%$ ethanol 추출물은 농도별로 $27.58 \%, 62.81 \%, 91.17 \%$ 로 $70 \%$ methanol 다음으로 높은 활성을 나타내었다. Chloroform:methanol $(2: 1, \mathrm{v} / \mathrm{v})$ 추출물은 $18.61 \%, 38.77 \%, 59.34 \%$, ethyl acetate 추출물은 $18.01 \%, 38.17 \%, 58.06 \%$ 의 활성을 나타내었으
며, n-butanol 추출물은 $17.47 \%, 37.42 \%, 57.77 \%$ 로 나타나 추출 용매 중 가장 낮은 활성을 보였다. 대조군인 ascorbic acid는 농도별로 $95.92 \%, 95.98 \%$ 및 $95.98 \%$ 의 활성을 나타 내는 것으로 측정되었다.

한편, DPPH는 짙은 보라색을 나타내는 안정한 free radical로 항산화 물질과 반응하면 radical을 소거시켜 탈색 되는 반응을 이용하여 측정하며 항산화 작용의 지표로 사용 되고 있다(30,31). Park 등(8)에 의하면 산사 methanol 추출 물에 있어서 용매 분획물의 DPPH 활성은 methanol 추출물 과 ethyl acetate 및 butanol 분획물이 대조군인 a-tocopherol 과 비슷한 활성을 나타내었다고 하였다. 또한, 산약 및 살구 씨, 산사, 지실을 물과 ethanol로 추출한 결과, 물 및 ethanol 추출물 모두에서 산사의 전자공여능이 가장 높게 나타났으 며 특히, ethanol 추출물 $1,000 \mathrm{ppm}$ 농도에서 $89 \%$ 의 높은 활성을 보여 산사는 free radical에 의한 lipid peroxidation을 감소시키는 효과가 높은 것으로 확인되어 있다(32).

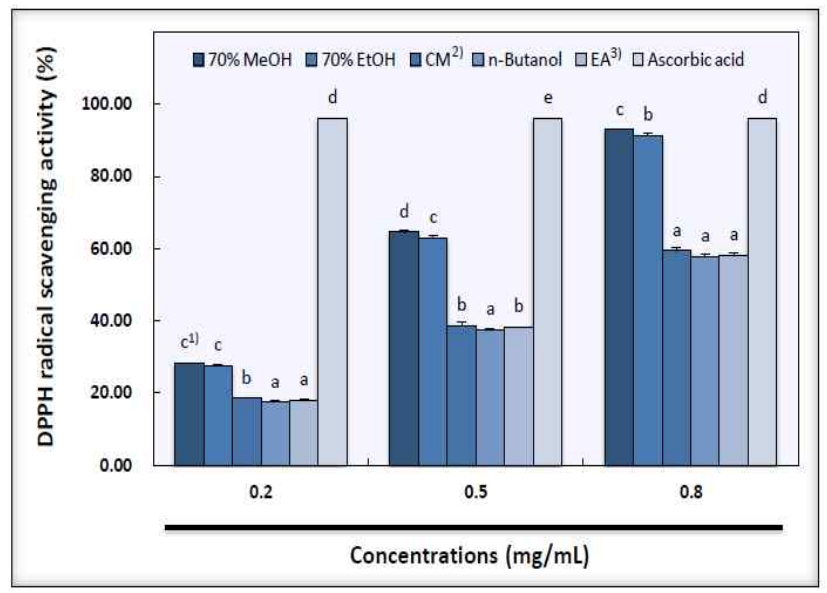

Fig. 1. DPPH radical scavenging activity of various solvent extracts of pulpy from haw (Crataegus pinnatifida Bunge).

${ }^{1)}$ The data are presented as means \pm SD of 3 times. Means with different letters are significantly different at $\mathrm{p}<0.05$ by Duncan's multiple range test. ${ }^{2)} \mathrm{CM}$; chloroform:methanol=2:1 (v/v).

${ }^{33} \mathrm{EA}$; ethyl acetate.

환원력

환원력은 산화를 일으킨 후 반응을 정지시키고 $\mathrm{FeCl}_{3}$ 를 첨가하여 $\mathrm{Fe}^{3+}$ 이 $\mathrm{Fe}^{2+}$ 로 환원되는 반응을 이용한 것으로 이때 $\mathrm{Fe}^{2+}$ 의 농도로 시료의 환원력을 측정 할 수 있으며, 흡광도 수치 그 자체로 환원력을 나타내므로 환원력이 우수 할수록 흡광도 수치가 크며 진하게 발색되는 것으로 알려져 있다(33). 산사 과육의 농도별 환원력은 Fig. 2 와 같이 시료 추출물의 농도가 높을수록 환원력은 증가하였으나 대조군 인 ascorbic acid(0.615, 1.340, 2.303)에 비하여 낮게 나타나 유의적인 차이를 보였다. 또한, 산사 과육의 모든 용매 추출 물에서 농도별로 유의적인 차이를 나타내었으며 과육의 $70 \%$ methanol 추출물이 농도별로 각각 $0.073,0.149,0.242$ 
로 다른 용매 추출물에 비하여 가장 높은 환원력을 나타내 었다. $70 \%$ ethanol이 $0.063,0.136,0.224$ 로 $70 \%$ methanol 다음으로 높은 활성을 나타내었다. n-butanol은 과육 추출물 농도에 따라 $0.048,0.096,0.162$, ethyl acetate 추출물은 $0.047,0.095,0.158$, chloroform:methanol $(2: 1, \mathrm{v} / \mathrm{v})$ 추출물이 $0.046,0.094,0.157$ 의 환원력을 보여 서로간의 유의적인 차이는 보이지 않았다.

한편, 산사의 환원력은 영지와 하수오 보다 높게 나타났 다고 하며(34), 시료의 농도가 증가할수록 환원력 또한 증가 하고 추출하는 용매에 따라 환원력의 차이는 크다고 보고되 어 있다(35). 이러한 실험 결과는 본 실험 결과와 유사한 것으로 $70 \%$ methanol 및 $70 \%$ ethanol 추출물에서 가장 높은 환원력을 보인 것은 추출 용매에 따른 성분의 조성 및 함량 등이 상이하기 때문이라고 생각된다.

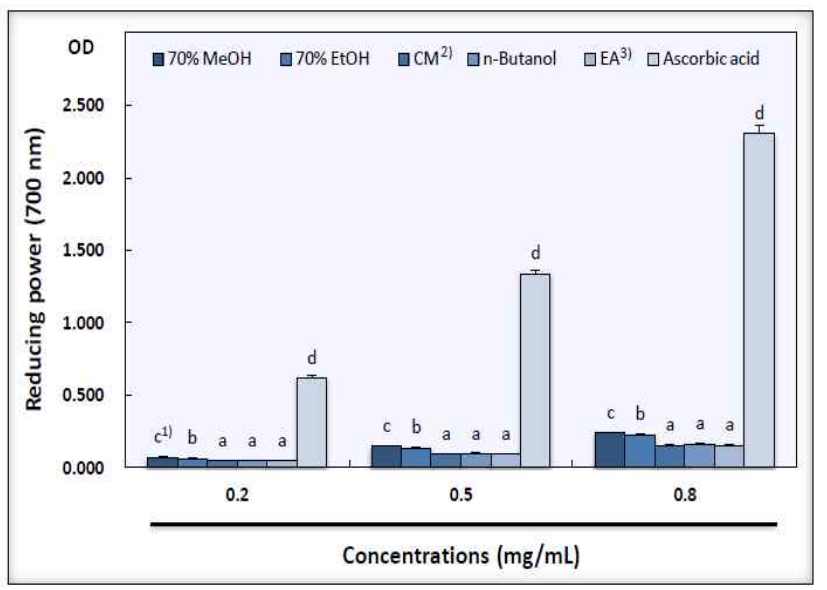

Fig. 2. Reducing power of various solvent extracts of pulpy from haw (Crataegus pinnatifida Bunge).

${ }^{1)}$ The data are presented as means \pm SD of 3 times. Means with different letters are significantly different at $\mathrm{p}<0.05$ by Duncan's multiple range test.

${ }^{2)} \mathrm{CM}$; chloroform:methanol $=2: 1(\mathrm{v} / \mathrm{v})$.

${ }^{3)} \mathrm{EA}$; ethyl acetate.

Ferric reducing antioxidant power(FRAP)

산사 과육의 용매 추출물에 따른 FRAP(ferric reducing antioxidant power) 활성은 Fig. 3과 같으며, 모든 추출물에서 농도별로 차이를 보였다. 산사 과육의 $70 \%$ methanol 추출물 은 시료 농도별로 각각 $0.107,0.242,0.409$ 의 활성을 나타내 었으며, $70 \%$ ethanol 추출물은 농도별로 $0.105,0.240,0.409$ 를 나타내어 $70 \%$ methanol 추출물의 활성이 높게 나타났다. 또한 chloroform:methanol $(2: 1, \mathrm{v} / \mathrm{v})$ 추출물은 농도별로 $0.070,0.151,0.250$ 의 활성을 나타내었으며, ethyl acetate 추출물이 $0.070,0.159,0.264$ 를 나타내어 ethyl acetate 추출 물이 높은 활성을 나타내었다. n-butanol 추출물은 농도별로 $0.078,0.160,0.269$ 의 활성을 보였다. $\mathrm{BHA}$ (butylated hydroxyanisole)는 농도별로 $0.851,1.808,2.054$ 의 활성을 나타내어 모든 용매 추출물과 유의적인 차이를 보였다.
한편, $\mathrm{FRAP}$ 는 $\mathrm{Fe}^{3+}-\mathrm{TPTZ}$ 복합체가 항산화 물질에 의해 $\mathrm{Fe}^{2+}-\mathrm{TPTZ}$ 로 환원되는 것을 이용한 것으로 재현성이 높고 간단하며 빠르게 측정할 수 있지만 free radical의 존재여부 보다 $\mathrm{Fe}^{3+} \rightarrow \mathrm{Fe}^{2+}$ 에 의한 항산화능만 측정이 가능하기 때문 에 환원력이 없는 항산화제는 측정이 불가능 하다는 한계가 있다 $(36,37)$. 다양한 과일을 과육, 껍질로 나눠 FRAP를 측 정하였을 때, 그 중 산사의 과육 및 껍질(13.41 mmol/100 $\mathrm{g}, 29.25 \mathrm{mmol} / 100 \mathrm{~g})$ 이 실험에 사용된 다른 과일 $(0.14 \sim 6.98$ $\mathrm{mmol} / 100 \mathrm{~g}, 0.25 \sim 16.69 \mathrm{mmol} / 100 \mathrm{~g}$ )에 비하여 월등히 높은 활성을 보였다고 하였다(38). 따라서 산사 과육의 FRAP 활성은 매우 높아 산사는 천연 항산화제로서 좋은 급원이 될 것으로 생각된다.

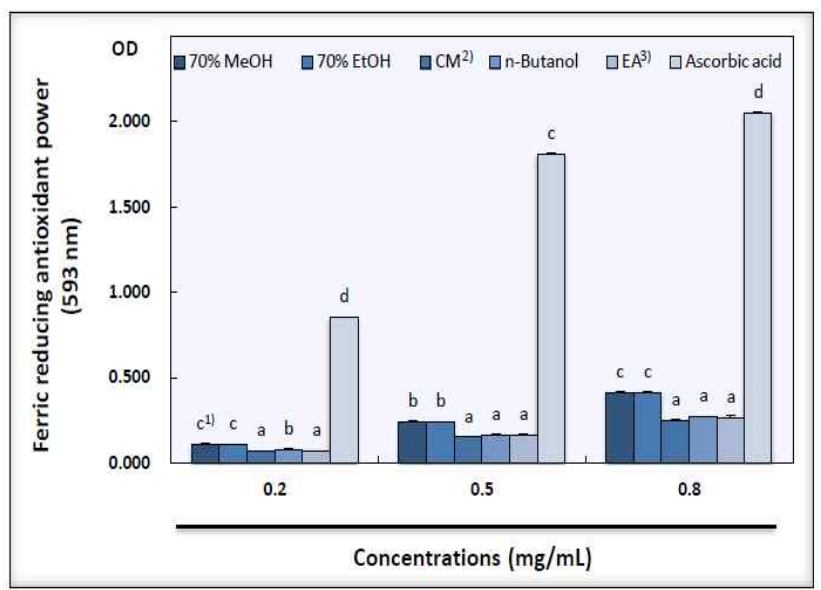

Fig. 3. Ferric reducing antioxidant power of various solvent extracts of pulpy from haw (Crataegus pinnatifida Bunge).

${ }^{1)}$ The data are presented as means \pm SD of 3 times. Means with different letters are significantly different at $p<0.05$ by Duncan's multiple range test.

${ }^{2} \mathrm{CM}$; chloroform:methanol=2:1 (v/v).

${ }^{33} \mathrm{EA}$; ethyl acetate.

\section{ABTS radical scavenging activity}

ABTS[2,2' -azino-bis(3-ethylbenzothiazoline-6-sulfonic acid) diammonium salt] radical 소거 활성의 측정은 시료 중의 항산화 물질이 ABTS radical을 제거하여 탈색되는 정도를 흡광도를 통해서 측정하는 방법으로, $\mathrm{DPPH}$ 시험법 은 free radical을 제거하는 것과 달리 ABTS 시험법은 양이 온을 제거하기 때문에 radical 제거 능력에서 차이를 보이며 지용성 및 수용성 물질을 모두 측정할 수 있다는 장점이 있다 $(39,40)$. 산사 과육의 ABTS radical 소거 활성은 Fig. 4와 같이, 대조군인 ascorbic acid 및 trolox를 제외한 용매간 의 활성도는 농도 의존적으로 증가하였으며 유의적인 차이 를 나타내었다. 산사 과육의 $70 \%$ methanol 추출물은 시료 농도별로 $18.41 \%, 44.96 \%, 75.81 \%$ 를 나타내어 용매 추출물 중 가장 높은 활성을 나타내었으며, $70 \%$ ethanol 추출물은 각각 $18.27 \%, 44.42 \%, 74.73 \%$ 를 나타내어 $70 \%$ methanol 다음으로 높은 활성을 보였다. Chloroform:methanol(2:1, 
$\mathrm{v} / \mathrm{v}$ ) 추출물은 농도별로 각각 $12.24 \%, 29.24 \%, 49.27 \%$ 를 나타내어 $70 \%$ ethanol 추출물 다음으로 높은 활성을 나타내 었다. Ethyl acetate 추출물은 시료 농도별로 $11.51 \%$, $27.77 \%, 48.24 \%$ 로 나타났고, n-butanol 추출물은 $11.31 \%$, $27.47 \%, 46.72 \%$ 로 용매 추출물 중 가장 낮은 활성을 보였다. 표준물질인 ascorbic acid는 농도별로 $99.56 \%, 99.66 \%$, $99.76 \%$ 를 나타내었고, trolox는 농도별로 각각 $95.10 \%$, $98.82 \%, 98.87 \%$ 의 활성을 보여 전 농도에서 $95 \%$ 이상의 높은 활성을 나타내었다. 한편, 대추 열매의 ABTS 소거 활성은 $20 \%$ 미만이었으나 잎에서는 최고 $98.33 \%$ 의 소거 활성을 보여 열매보다 잎에서 높은 $\mathrm{ABTS}$ 소거 활성을 나타 내었다는 보고도 있다(41). 또한, 국내에서 시판되는 다류 의 항산화력을 측정하였을 때, 녹차와 홍차류가 활성이 높 은 것으로 보고되어 있으며 $\mathrm{DPPH}$ 와 $\mathrm{ABTS}$ 간에 높은 상관 관계를 보였다고 한다(42). 따라서 본 실험 결과에서도 산사 과육의 $\mathrm{ABTS}$ 소거활성은 $\mathrm{DPPH}$ 와 동일한 경향을 나타내 었다.

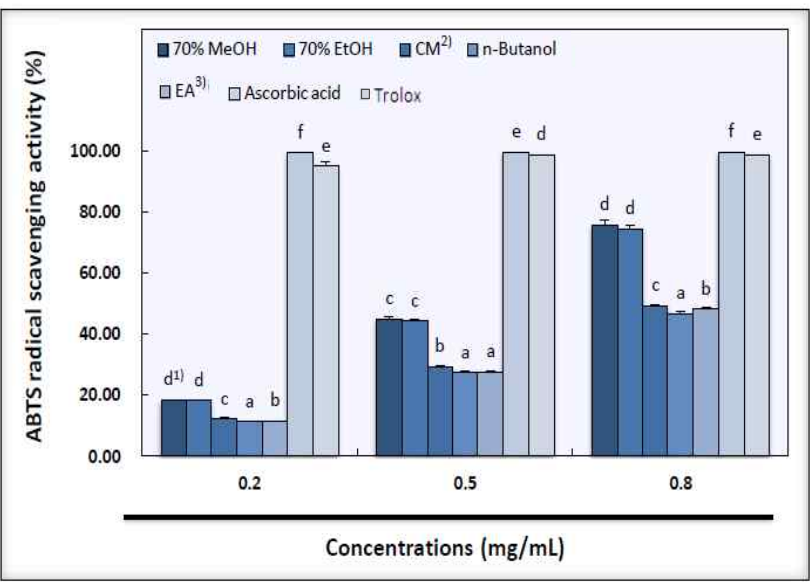

Fig. 4. ABTS radical scavenging activity of various solvent extracts of pulpy from haw (Crataegus pinnatifida Bunge).

${ }^{1)}$ The data are presented as means \pm SD of 3 times. Means with different letters are significantly different at $\mathrm{p}<0.05$ by Duncan's multiple range test.

${ }^{2)} \mathrm{CM}$; chloroform:methanol=2:1 (v/v)

${ }^{3)}$ EA; ethyl acetate.

NO radical scavenging activity

용매별 추출물의 NO radical 소거 활성은 Fig. 5 와 같으며, 모든 추출물에서 농도 의존적으로 활성의 증가를 나타내었 다. 과육의 $70 \%$ methanol 추출물은 시료 농도별로 $25.24 \%$, $30.37 \%, 38.85 \%$ 의 소거 활성을 보였고, $70 \%$ ethanol 추출물 은 농도별로 $17.72 \%, 29.10 \%, 36.21 \%$ 를 보였다. Ethyl acetate 추출물이 $17.00 \%, 23.11 \%, 32.61 \%$ 로 $70 \%$ methanol 및 $70 \%$ ethanol 추출물 다음으로 높은 소거 활성을 나타내 었고 n-butanol 추출물이 농도별로 각각 $13.44 \%, 23.09 \%$, $30.40 \%$ 로 ethyl acetate 추출물 다음으로 높은 소거능을 보 였다. Chloroform:methanol(2:1, v/v) 추출물이 $4.56 \%$,
$15.36 \%, 24.29 \%$ 의 소거 활성을 보여 용매 추출물 중 가장 낮았다. 대조군인 BHA는 농도별로 $43.68 \%, 94.34 \%$, $95.30 \%$ 를 나타내었으며 용매별 추출물과도 유의적인 차이 를 나타내는 것으로 확인 되었다.

한편, NO radical은 단시간에 작용하는 free radical로 신 경 신호 전달의 이차 전령체(secondary messenger), 평활근 이완, 혈소판 응집 저해, 세포매개 독성과 같은 생리적 과정 의 매개체 및 염증 관련 인자로 알려져 있다 $(43,44)$. 녹색 함초 $25 \%$ ethanol 추출물은 빨간 함초 $25 \%$ ethanol 추출물 보다 높은 소거능을 보였고 시료 농도가 증가할수록 높아지 는 경향을 나타내었으며(28), 산사 및 인삼 $15 \mathrm{~g}$ 의 추출물은 염증성 반응에 중요한 영향을 하는 $\mathrm{NO}$ 의 생성을 억제 하여 Alzheimer성 치매의 치료에 유효할 것이라고 보고되어 있 다(45). 따라서 산사는 NO radical 소거능이 뛰어나 기능성 소재로서 응용될 수 있을 것으로 생각 된다.

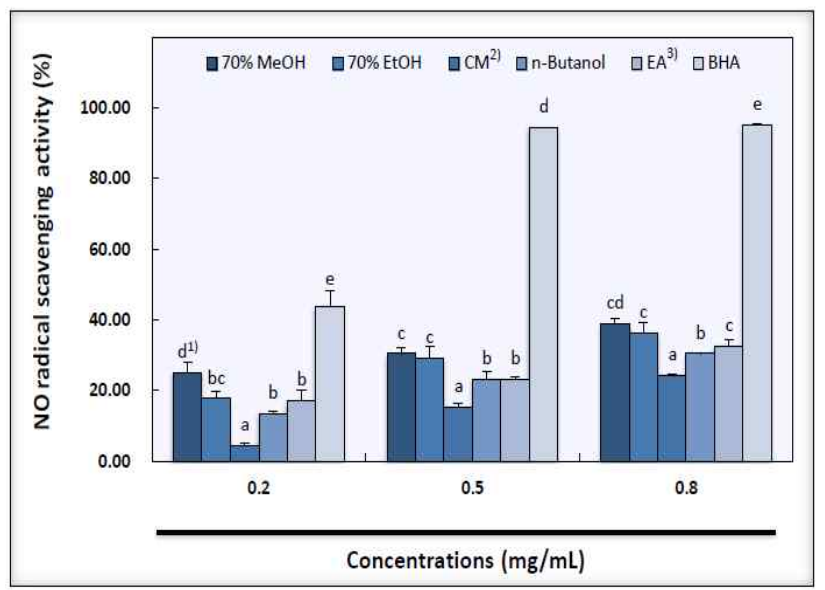

Fig. 5. NO radical scavenging activity of various solvent extracts of pulpy from haw (Crataegus pinnatifida Bunge).

${ }^{1)}$ The data are presented as means $\pm \mathrm{SD}$ of 3 times. Means with different letters are significantly different at $\mathrm{p}<0.05$ by Duncan's multiple range test. ${ }^{2)} \mathrm{CM}$; chloroform:methanol=2:1 (v/v).

${ }^{3)} \mathrm{EA}$; ethyl acetate

Hydroxyl radical scavenging activity

Hydroxyl radical은 $\mathrm{Fe}^{2+}$ 와 $\mathrm{H}_{2} \mathrm{O}_{2}$ 가 반응하는 Fenton's reaction에 의해 생성 되는 반응성이 강한 free radical로 지 질, 단백질, poly peptide 및 DNA 등과 반응한다고 알려져 있으며, Fenton system에 의해 생성되어진 hydroxyl radical 이 2-deoxyribose를 산화시켜 malondialdehyde(MDA)로 분 해시키는 원리를 이용하여 측정한다고 보고되어져 있다 $(29,46)$. 산사 과육의 hydroxyl radical 소거 활성은 Fig. 6과 같으며 모든 추출물에서 농도가 증가함에 따라 소거 활성도 증가하는 것으로 나타났다. Ethyl acetate 추출물이 농도별 로 각각 $3.67 \%, 11.08 \%, 20.65 \%$ 로 나타나 추출 용매 중 가장 낮은 소거 활성을 보였다. 또한, chloroform:methanol 
$(2: 1, \mathrm{v} / \mathrm{v})$ 추출물은 $10.91 \%, 25.29 \%, 35.33 \%$ 로 ethyl acetate 추출물 다음으로 낮은 소거 활성을 나타내었다. $70 \%$ methanol 추출물은 농도별로 $14.03 \%, 28.79 \%, 41.63 \%, 70 \%$ ethanol 추출물은 농도별로 각각 $13.90 \%, 27.22 \%, 39.62 \%$ 의 소거 활성을 나타내었다. n-butanol은 농도별로 $26.52 \%$, $40.83 \%, 47.44 \%$ 의 소거능을 보여 추출 용매 중 가장 높게 나타났다. 대조군인 $\mathrm{BHA}$ 는 농도별로 각각 $89.23 \%$, $90.59 \%, 92.03 \%$ 를 나타내어 다른 용매 추출물보다 높은 소거능을 보였다.

한편, 오미자 열수추출물의 hydroxyl radical 소거능은 $500 \mathrm{\mu g} / \mathrm{mL}$ 농도에서 $58.7 \%$ 이었으며 대조군인 BHT는 $68.3 \%$ 의 소거 활성이 있는 것으로 나타났고(47), 두릅나무 의 추출 용매별 hydroxyl radical 소거 활성은 acetone, chloroform, ethanol, methanol, water 순이었으며, 특히 물 추출물에서는 거의 활성이 나타나지 않았고 hydroxyl radical은 지질과산화 억제와 연관이 있다고 보고되어 있다 (29). 여주의 부위별 hydroxyl radical 소거 활성은 풋열매에 서 $39.7 \%$, 잎은 $39.2 \%$, 줄기에서는 $34.0 \%$ 의 활성을 보였다 고 한다(48). 본 실험 결과 n-butanol 및 $70 \%$ methanol 추출물 에서 hydroxyl radical 소거 활성이 높게 나타났다.

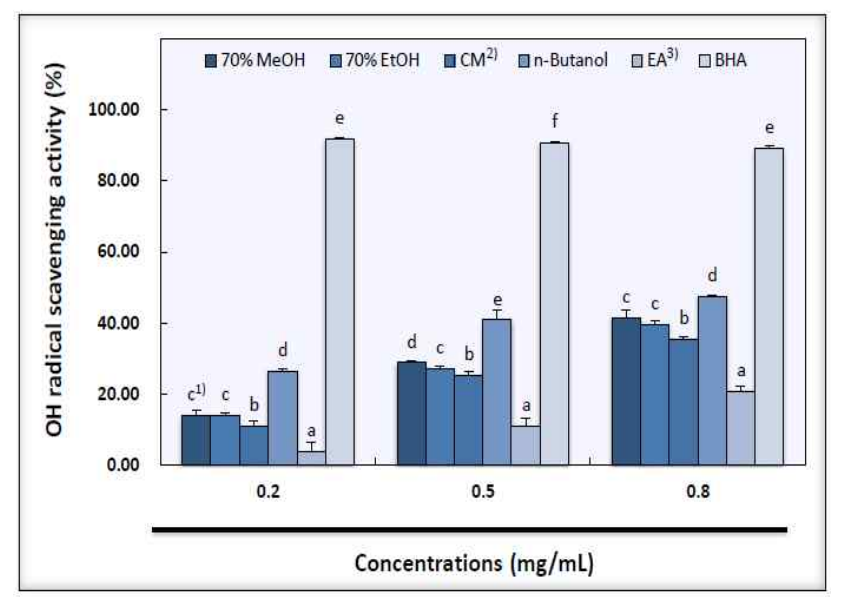

Fig. 6. Hydroxyl radical scavenging activity of various solvent extracts of pulpy from haw (Crataegus pinnatifida Bunge).

${ }^{1)}$ The data are presented as means \pm SD of 3 times. Means with different letters are significantly different at $\mathrm{p}<0.05$ by Duncan's multiple range test. ${ }^{2)} \mathrm{CM}$; chloroform:methanol=2:1 (v/v)

${ }^{3)} \mathrm{EA}$; ethyl acetate.

\section{요 약}

산사 과육을 $70 \%$ methanol, $70 \%$ ethanol, chloroform:methanol (CM, 2:1, v/v), n-butanol, ethyl acetate(EA)로 추출하여 시료 농도 $0.2 \mathrm{mg} / \mathrm{mL}, 0.5 \mathrm{mg} / \mathrm{mL}, 0.8 \mathrm{mg} / \mathrm{mL}$ 농도에서 각 추출물 의 항산화 활성을 비교하였다. DPPH radical 소거 활성은 $70 \%$ methanol, $70 \%$ ethanol, chloroform:methanol(2:1, v/v), ethyl acetate, n-butanol 추출물 순으로 높게 측정되었고 특 히 $70 \%$ methanol 및 $70 \%$ ethanol 추출물은 다른 추출물에 비하여 유의적으로 높은 것으로 나타났으며 $(\mathrm{p}<0.05), 0.8$ $\mathrm{mg} / \mathrm{mL}$ 농도에서 각각 $92.89 \%, 91.17 \%$ 의 높은 활성을 나타 내었다. 환원력과 ferric reducing antioxidant power(FRAP) 는 동일한 경향을 나타내었는데 활성은 $70 \%$ methanol, $70 \%$ ethanol, n-butanol, ethyl acetate, chloroform: methanol(2:1, $\mathrm{v} / \mathrm{v}$ ) 추출물 순으로 높게 나타났으며, $70 \%$ methanol 및 $70 \%$ ethanol 추출물이 다른 추출물에 비하여 높은 것으로 측정 되었다 $(\mathrm{p}<0.05)$. ABTS radical 소거 활성은 $\mathrm{DPPH}$ 와 동일한 경향이었으며 $0.8 \mathrm{mg} / \mathrm{mL}$ 농도에서 $70 \%$ methanol 및 $70 \%$ ethanol 추출물은 각각 $75.81 \%, 74.73 \%$ 의 활성을 나타내었 다. NO radical 소거 활성은 $70 \%$ methanol, $70 \%$ ethanol, ethyl acetate, n-butanol, chloroform:methanol $(2: 1, \mathrm{v} / \mathrm{v})$ 추출 물 순으로 나타났고, hydroxyl radical 소거 활성은 n-butanol, $70 \%$ methanol, $70 \%$ ethanol, chloroform: methanol(2:1, v/v), ethyl acetate 추출물 순으로 측정되었다. Hydroxyl radical 소거 활성을 제외한 다른 실험 결과에서 $70 \%$ methanol 및 $70 \%$ ethanol 추출물은 다른 용매 추출물에 비하여 유의적으 로 높은 것으로 나타났고 chloroform: methanol $(2: 1, \mathrm{v} / \mathrm{v})$, ethyl acetate, n-butanol 추출물 간에는 대부분 유의성이 없 는 것으로 측정되었다 $(\mathrm{p}<0.05)$. 본 실험 결과 산사 과육 추 출물의 항산화 활성은 우수한 것으로 나타났고 특히, $70 \%$ methanol 및 $70 \%$ ethanol 추출물에서 높은 활성을 보였다. 따라서 산사는 천연 항산화제 및 기능성 식품 소재로서 활용될 수 있을 것으로 생각된다.

\section{감사의 글}

이 논문은 부산대학교 자유과제 학술연구비(2년)에 의하 여 연구되었음.

\section{References}

1. Seo YJ, Kim MH, Kim MH, Choi MK (2012) Status and relationships among lifestyle, food habits, and stress scores of adults in Chungnam. Korean J Community Nutr, 17, 579-588

2. Park JK, Kweon SH, Kim YH, Jang MJ, Oh KW (2012) Dietary behaviors related to metabolic syndrome in Korean adults. Korean J Community Nutr, 17, 664-675

3. Liu RH (2003) Health benefits of fruit and vegetables are from additive and synergistic combinations of phytochemicals. Am J Clin Nutr, 78, 517-520

4. Han JS, Rhee SH (1996) The relationship between serum 
cholesterol level and dietary intake in obese children. J Korean Soc Food Nutr, 25, 433-440

5. Kim JY, Lee CR, Cho KH, Lee JH, Lee KT (2009) Antioxidative and Lp-PLA 2 inhibitory activities in 29 fruits and vegetables. Korean J Food Preserv, 16, 512517

6. Kang JY, Kim SY, Lee MS, Ahn HS (2005) Effects of vegetables juice supplementation on serum lipid profile and antioxidant activity in college women. Korean $\mathbf{J}$ Community Nutr, 10, 183-188

7. Bae MH, Kim HH (2003) Mechanism of Crataegi fructus extract induced endothelium-dependent vasorelaxation in rabbit carotid artery. Kor J Herbology, 18, 169-180

8. Park SJ, Shin EH, Lee JH (2012) Biological activities of solvent fractions from methanolic extract of Crataegi fructus. Korean J Food Nutr, 25, 897-902

9. Chon JW, Park SJ, Han JH, Park SH (2005) Study of Crataegi fructus for medicinal foods applications nutrition composition and scheme for foods. Korean $\mathbf{J}$ Oriental Physiol Pathol, 19, 1220-1224

10. Kim JS, Lee GD, Kwon JH, Yoon HS (1993) Identification of phenolic antioxidative components in Crataegus pinnatifida Bunge. J Korean Agric Chem Soc, 36, 154-157

11. Liu P, Yang B, Kallio H (2010) Characterization of phenolic compounds in chinese hawthorn (Crataegus pinnatifida Bge. var. major) fruit by high performance liquid chromatography lectrospray ionization mass spectrometry. Food Chem, 121, 1188-1197

12. Lim JD, Yu CY, Kim MJ, Yun SJ, Lee SJ, Kim NY, Chung IM (2004) Comparison of SOD activity and phenolic compound contents in various Korean medicinal plants. Korean J Medicinal Crop Sci, 12, 191-202

13. Ryu SN (2000) Recent process and future of research on anthocyanin in crops I rice, barley, wheat, maize and legumes. Korean J Int Agric, 12, 41-53

14. Tadic VM, Dobric S, Markovic GM, Dordevic SM, Arsic IA, Menkovic NR, Stevic T (2008) Anti-inflammatory, gastroprotective, free radical scavenging and antimicrobial activities of hawthorn berries ethanol extract. J Agric Food Chem, 56, 7700 - 7709

15. Won SH, Kwon KR, Rhim TJ, Kim DH (2008) The effect of Crataegi Fructus pharmacopuncture on adipocyte metabolism. J Pharmacopuncture, 11, 63-73

16. Park SH, Kim YH, Chon JW, Song YJ, Han JH (2005) Study of Crataegi Fructus for medicinal foods applications functional evaluation of fermented liquid on the lipid profile improvement high fat diet. Korean $\mathbf{J}$ Oriental Physiol, 19, 1272- 1280

17. Wang SB, Ahn EM, Jung JW (2009) The fruits of Crataegus pinnatifida Bunge ameliorates learning and memory impairments induced by scopolamine. Kor $\mathbf{J}$ Herbology, 24, 165-171

18. Lee HJ, Choi MS (1999) Measurement of inhibitory activities on 3-hydroxy-3-methylglutaryl CoA reductase and acyl-CoA:cholesterol acyltransferase by various plant extracts in vitro. J Korean Soc Food Sci Nutr, 28, 958-962

19. Hong SS, Hwang JS, Lee SA, Han XA, Ro JS, Lee KS (2002) Inhibitors of monoamine oxidase activity from the fruits of Crataegus pinnatifida Bunge. Korean $\mathbf{J}$ Pharmacogn, 33, 285-290

20. Kim KH, Lee SS, Baek JW, Lee SJ, Kim KH (2004) Effect of Crataegii fructus on antioxidant capacity in D-galactose induced aging rats. Korean J Oriental Preventive Medical Soc, 8, 65-80

21. Jang EH, Pyo YH, Ahn MS (1996) Antioxidant effect of omija (Schizandra chinesis Baillon) extracts. Korean J Soc Food Sci, 12, 372-376

22. Blois MS (1958) Antioxidant determination by the use of a stable free radical. Nature, 26, 1198-1200

23. Jin YW, Fook YC (2009) Antioxidant properties of selected tropical wild edible mushrooms. J Food Compos Anal, 22, $269-277$

24. Jeong CH, Jang CW, Lee KY, Kim IH, Shim KH (2012) Chemical components and antioxidant activities of black currant. Korean J Food Preserv, 19, 263-270

25. Re R, Pellegrini N, Proteggente A, Pannala A, Yang M, Rice-Evans C (1999) Antioxidant activity applying an improved ABTS radical cation decolorization assay. Free Radic Biol Med, 26, 1231-1237

26. Yang SA, Cho JH, Pyo BS, Kim SM, Lee KI (2012) Comparison of the physiological activities of extracts from different parts of Prunus sargentii. Korean J Medicinal Crop Sci, 20, 159-164

27. Shrishailappa Badami S, Gupta MK, Suresh B (2003) Antioxidant activity of the ethanolic extract of Striga orobanchioides. J Ethnopharmacol, 85, 227-230

28. Song HS, Kim DP, Jung YH, Lee MK (2007) Antioxidant activities of red hamcho (Salicornia herbacea L.) against lipid peroxidation and the formation of radicals. Korean J Food Nutr, 20, 150-157

29. Hu W, Jung MJ, Heo SI, Wang MH (2008) Antioxidant and antidiabetic activities of Aralia elata seeds. J Appl Biol Chem, 51, 111-116 
30. Lee JM, Chang PS, Lee JH, (2007) Comparison of oxidative stability for the thermally-oxidized vegetable oils using a DPPH method. Korean J Food Sci Technol, 39, 133-137

31. Lee SH, Kang KM, Park HJ, Baek LM (2009) Physiological characteristics of medicinal plant extracts for use as functional materials in seasoning sauce for pork meat. Korean J Food Sci Technol, 41, 100-105

32. Park CS, Yang KM, Kim ML (2006) Functional properties of medicinal plant extracts. Korean J Food Cookery Sci, 23, 720-727

33. Chung HJ (2010) Antioxidative activities of different part extracts of Physalis alkekengi var. francheti (winter cherry). Korean J Food Preserv, 17, 867-873

34. Lee SJ, Shin JH, Kang MJ, Yang SM, Ju JC, Sung NJ (2009) Effect of garlic and medicinal plants composites on antioxidant activity and lipid levels of liver in hypercholesterolemic rats. J Life Sci, 19, 1769-1776

35. Ju JC, Shin JH, Lee SJ, Cho HS, Sung NJ (2006) Antioxidative activity of hot water extracts from medicinal plants. J Korean Soc Food Sci Nutr, 35, 7-14

36. Benzie IFF, Strain JJ (1999) Ferric reducing/antioxidant power assay:direct measure of total antioxidant activity of biological fluids and modified version for simultaneous measurement of total antioxidant power and ascorbic acid concentration. Methods Enzymol, 299, 15-27

37. Cao G, Prior PL (1998) Comparison of different analytical methods for assessing total antioxidant capacity of human serum. Clin Chem, 44, 1309-1315

38. Guo C, Yang J, Wei J, Li Y, Xu J, Jiang Y (2003) Antioxidant activities of peel, pulp and seed fractions of common fruits as determined by FRAP assay. Nutr Res, 23, 1719-1726

39. Jung EH, Hwang IK, Ha TY (2010) Properties and antioxidative activities of phenolic acid concentrates of rice bran. Korean J Food Sci Technol 42, 593-597
40. Kim MJ, Lee HH, Seo MJ, Kang BW, Park JU, Jeong YK (2013) Antioxidation activities of organic solvent fractions obtained from seaweed, Hizikia fusiformis. J Life Sci, 23, 361-367

41. Kim IH, Jeong CH, Park SJ, Shim KH (2011) Nutritional components and antioxidative activities of jujube (Zizyphus jujuba) fruit and leaf. Korean J Food Preserv, 18, 341-348

42. Choi YM, Kim MH, Shin JJ, Park JM, Lee JS (2003) The antioxidant activities of the some commercial teas. J Korean Soc Food Sci Nutr, 32, 723-727

43. Choi YH, Yang HM, Lee JH, Choi JS, Kang YH, Shin SR, Park YW, Kim DY, Chang JD, Lee SS (2006) Influences of particles on pro-inflammatory signalings in pre-osteoclasts. J Korean Orthopaedic Res Soc, 9, $18-28$

44. Kumar S, Kumar D, Jusha M, Saroha K, Singh N, Vashishta B (2008) Antioxidant and free radical scavenging potential of Citrullus colocynthis (L.) Schrad. methanolic fruit extract. Acta Pharm, 58, 215-220

45. Han SH, Kil GJ (2007) A study on the therapeutic effect of Alzheimer's disease of ginseng radix plus Crataegi fructus. Kor J Herbology, 22, 35-40

46. Guo Q, Rimbach G, Moini H, Weber S, Packer L (2002) ESR and cell culture studies on free radical-scavenging and antioxidant activities of isoflavonoids. Toxicol, 179, 171-180

47. Kim JS, Choi SY (2008) Physicochemical properties and antioxidative activities of Omija (Schizandra chinensis Bailon). Korean J Food Nutr, 21, 35-42

48. Kubola J, Siriamornpun S (2008) Phenolic contents and antioxidant activities of bitter gourd (Momordica charantia L.) leaf, stem and fruit fraction extracts in vitro. Food Chem, 110, 881-890

(접수 2014년 1월 8일 수정 2014년 3월 6일 채택 2014년 3월 13일) 